\title{
IN MEMORIAM, ROGER E. MILLSAP 1954-2014
}

\section{Alberto MAYdeu-Olivares}

\author{
UNIVERSITY OF BARCELONA
} 2014.

The Editor-in-Chief of Psychometrika, Roger E. Millsap, passed away suddenly on May 9,

Roger Millsap was a born editor. He will be remembered by his colleagues for his ten-year term as editor of Multivariate Behavioral Research from 1996 to 2006, during which time he led the journal to be one of the most widely cited in the field. From 2007 until the time of his death, he was Editor-in-Chief of Psychometrika, and led this journal to a period of unprecedented success, in which it almost doubled its impact. In addition, he edited the monumental Sage Handbook of Quantitative Methods in Psychology (Millsap \& Maydeu-Olivares, 2009) and initiated the regular publication of the proceedings of the Psychometric Society meetings (Millsap, van der Ark, Bolt, \& Woods, 2013).

A vegetarian and a Buddhist, Roger Millsap was a very modest man, so much so that in his vita he did not list the numerous awards he received during his career. Among them, the following deserve special mention: the Cattell Award (1993) for early career contributions in multivariate experimental psychology, the Tanaka Award (1995, 1999, and 2005) for the most outstanding publication in Multivariate Behavioral Research, and the Herb Eber Award (2001) for outstanding service to the Society for Multivariate Experimental Psychology.

It is testimony to his ability and his warmth as a human being that he was elected to serve as president in all the scientific societies in which he was involved: the Society for Multivariate Experimental Psychology (2001), Division 5 of the American Psychological Association (2004), and the Psychometric Society (2006). Through his editorial roles and presidencies of scientific societies, he shaped the field of quantitative psychology into what it is today.

Roger Millsap received a BS from the University of Washington (1977), an MA in Statistics (1983), and a Ph.D. in Quantitative Psychology (1983) from the University of California, Berkeley, where he worked under the supervision of Bill Meredith. Upon graduation and until 1997, he taught at the Industrial/Organizational program at City University of New York, Baruch College, achieving the rank of full professor. In 1997, he moved to the Quantitative Research Methods program at the Psychology Department of Arizona State University where he worked until his sudden and untimely death.

With almost 100 academic publications, Roger Millsap was best known for his work on assessing measurement invariance (Meredith \& Millsap, 1992; Millsap \& Everson, 1993; Meredith \& Millsap, 2004; Millsap \& Yun-Tein, 1995; Millsap, 2005; Millsap, 2007). Fortunately for our field, shortly before his death he completed a long-awaited book summarizing his research in the area, entitled Statistical approaches to measurement invariance (Millsap, 2011). This is sure to be a classic reference work for many years to come.

Roger is survived by his wife Michele and his children: Mason Jamal, Laura Caitlin, Simone Elizabeth, and Aiden Patrick. 


\section{References}

Meredith, W., \& Millsap, R. E. (1992). On the misuse of manifest variables in the detection of measurement bias. Psychometrika, 57(2), 289-311. doi:10.1007/BF02294510.

Millsap, R. E., \& Everson, H. T. (1993). Methodology review: Statistical approaches for assessing measurement bias. Applied Psychological Measurement, 17(4), 297-334. doi:10.1177/014662169301700401.

Millsap, R. E. (1995). Measurement invariance, predictive invariance, and the duality paradox. Multivariate Behavioral Research, 30(4), 577-605. doi:10.1207/s15327906mbr3004_6.

Millsap, R. E., \& Yun-Tein, J. (2004). Assessing factorial invariance in ordered-categorical measures. Multivariate Behavioral Research, 39(3), 479-515. doi:10.1207/S15327906MBR3903_4.

Millsap, R. E. (2005). Four unresolved problems in studies of factorial invariance. In A. Maydeu-Olivares \& J. J. McArdle (Eds.), Contemporary psychometrics. A Festschrift for Roderick P. McDonald (pp. 153-171). Mahwah, NJ: Erlbaum.

Millsap, R. E. (2007). Invariance in measurement and prediction revisited. Psychometrika, 72(4), 461-473. doi:10.1007/ s11336-007-9039-7.

Millsap, R. E., \& Maydeu-Olivares, A. (2009). The sage handbook of quantitative methods in psychology. London: Sage Publications.

Millsap, R. E. (2011). Statistical approaches to measurement invariance. New York: Routledge.

Millsap, R.E., van der Ark, L.A., Bolt, D.M., \& Woods, C.M. (Eds.). (2013). New developments in quantitative psychology (Vol. 66). New York: Springer. doi:10.1007/978-1-4614-9348-8.

Published Online Date: 31 JUL 2014 